HORTSCIENCE 25(3):351-353. 1990.

\title{
Observations on the Relationships among Seed Number, Fruit Calcium, and Senescent Breakdown in Apples
}

\author{
W.J. Bramlage, S.A. Weis, and D.W. Greene \\ Department of Plant and Soil Sciences, University of Massachusetts, \\ Amherst, MA 01003
}

Additional index words. Malus domestica, naphthaleneacetic acid, gibberellin, 6benzylamiuopurine

\begin{abstract}
In a population of 'Delicious' apples (Malus domestica Borkh.) with varying seed number at harvest, fruit size and Ca concentration in fruit increased with seed number. Neither $\mathrm{K}$ nor $\mathrm{Mg}$ concentration in fruit was related to seed number. In another population of 'McIntosh' apples from 50 commercial orchard blocks, the percentage of fruit that developed senescent breakdown, a Ca-deficiency disorder, decreased linearly as seed number per fruit increased. Low seed number is probably a factor contributing to $\mathrm{Ca}$ deficiency in apple fruit.
\end{abstract}

Previously, we reported that spraying 'McIntosh' apple trees with gibberellins $\mathrm{A}_{4+7}$ $\left(\mathrm{GA}_{4+7}\right)$ and $\mathrm{N}$ - (phenylmethyl)-1H-purine-6amine (BA) 17 days after full bloom resulted in decreased $\mathrm{Ca}$ concentrations in mature fruit as growth regulator concentrations increased (Greene et al., 1982). Looney (1979) reported similar findings with 'Spartan' apples

Received for publication 3 Jan. 1989. Massachusetts Agr. Expt. Sta. Paper 2916. This research was supported in part by Expt. Sta. projects 497 and 517. The cost of publishing this paper was defrayed in part by the payment of page charges. Under postal regulations, this paper therefore must be hereby marked advertisement solely to indicate this fact. and attributed the lower $\mathrm{Ca}$ concentration to the diluting effect of increased fruit size. In our study, we recorded increasing numbers of seedless fruit and increasing incidences of senescent breakdown (a Ca-deficiency disorder), along with decreasing $\mathrm{Ca}$ concentration, as $\mathrm{GA}_{4}+7$ and $\mathrm{BA}$ concentrations increased. Since parthenocarpic apples tend to be Ca-deficient (Bangerth, 1976), seed number may be a factor in determining $\mathrm{Ca}$ concentration in fruit at harvest. However, because our fruit had been sampled for mineral analyses without regard for seed number and with avoidance of fruit with breakdown, interrelationships among seed number, fruit $\mathrm{Ca}$, and senescent breakdown could not be tested. 
Table 1. Relationship of seed number per fruit in mature 'Richared Delicious' apples to fruit diameter and mineral composition.

\begin{tabular}{lcccc}
\hline \hline $\begin{array}{l}\text { Seed } \\
\text { no. } \\
\text { per fruit }\end{array}$ & $\begin{array}{l}\text { Fruit } \\
\text { diam } \\
(\mathrm{mm})\end{array}$ & $\begin{array}{c}\mathrm{Ca}^{\mathrm{y}} \\
(\mathrm{ppm})\end{array}$ & $\begin{array}{c}\mathrm{Mg} \\
(\mathrm{ppm})\end{array}$ & $\begin{array}{c}\mathrm{K} \\
(\%)\end{array}$ \\
\hline $0-1$ & 67 & 174 & 284 & 0.68 \\
$2-3$ & 70 & 208 & 278 & 0.66 \\
$4-5$ & 71 & 215 & 279 & 0.65 \\
$>5$ & 72 & 223 & 280 & 0.66 \\
\hline
\end{tabular}

${ }^{\mathrm{z}}$ Mean number of fruit per category $=179$.

${ }^{\mathrm{y}}$ Increase in $\mathrm{Ca}$ concentration significant at $P<$ 0.001

Table 2. Relationship of seed number per fruit in mature 'McIntosh' apples to the occurrence of senescent breakdown after storage in 0C air for 5 months plus 1 week at 24C. About 100 fruit were collected from each of 50 commercial orchard blocks in Massachusetts.

\begin{tabular}{ccc}
\hline \hline & $\begin{array}{c}\text { Fruit within } \\
\text { category that } \\
\text { developed } \\
\text { senescent } \\
\text { breakdown }\end{array}$ \\
$\begin{array}{c}\text { No. of } \\
\text { seeds/fruit }\end{array}$ & $\begin{array}{c}\text { No. of } \\
\text { fruit/category }\end{array}$ \\
\hline $0-1$ & 227 & 23 \\
$2-3$ & 441 & 18 \\
$4-5$ & 841 & 13 \\
$6-7$ & 1125 & 11 \\
$8-9$ & 1339 & 8 \\
$>9$ & 238 & 7 \\
\hline
\end{tabular}

${ }^{\mathrm{z}}$ Decrease is linear, $P<0.001$.

Here we report observations made during two subsequent experiments conducted for other purposes, but which created populations of mature apples with varying seed number and provided some insight into the relationships among seed number, fruit $\mathrm{Ca}$ concentration, and incidence of senescent breakdown. These observations suggest a quantitative relationship between seed number and $\mathrm{Ca}$ accumulation.

In a growth regulator experiment to test chemical thinning, treatments were applied to 8-year-old 'Richared Delicious'/MM.106 trees. Trees were separated into seven blocks (replications) of four trees each. Two trees in each block were sprayed 1 day before full bloom with a dilute application of $2.5 \mathrm{ppm}$ each of $\mathrm{GA}_{4+7}+\mathrm{BA}$ as the proprietary compound Promalin (Abbott Laboratories, North Chicago, Ill.) in 0.125\% Glyodin. 1Napthaleneacetic acid (NAA) at 6 ppm was applied 16 days after full bloom on one tree previously sprayed with $\mathrm{GA}_{4+7}+\mathrm{BA}$, and on one tree not previously sprayed, in each group.

At commercial harvest, $20 \mathrm{~kg}$ of fruit were taken at random from each tree and stored at $0 \mathrm{C}$ in air for 6 months. At removal from storage, diameter of each fruit was measured, each fruit was cut equatorially, and seeds that appeared to be viable were counted. An equatorial slice $1 \mathrm{~cm}$ thick was taken from each apple and slices were segregated according to seed number within each sample. Up to 16 slices were taken from each seed category per treatment and replication, and four cylinders of tissue $1 \mathrm{~cm}$ in diameter were taken-from each slice just beneath the peel, using a cork borer. These cylinders were dried, ground, and analyzed for $\mathrm{Ca}, \mathrm{Mg}$, and $\mathrm{K}$ according to the procedures of Weis et al. (1980).

The general effects of these growth regulator treatments were reported elsewhere (Greene and Lord, 1985). Of interest here is that the treatments produced a population of mature fruit with widely varying seed numbers. Although treatments influenced fruit mineral concentrations, an analysis of variance showed that there was no interaction between treatment and seed number on mineral concentration in mature fruit. Consequently, we were able to examine the independent relationship between seed number and mineral concentrations. However, fruit size was variable among the samples, and $\mathrm{Ca}$ concentration decreases as fruit size increases (Perring and Jackson, 1975). Thus, to examine the effects of seed number on mineral accumulation without a confounding effect from variable fruit size, fruit diameter was eliminated as a variable using covariance. Diameter was a significant covariant with $\mathrm{Mg}(\mathrm{P}<0.05)$, but not with $\mathrm{Ca}$ or $\mathrm{K}$.

As seed number per fruit increased, there was a significant $(\mathrm{P}<0.001)$ increase in fruit $\mathrm{Ca}$ concentration (Table 1). Because seed numbers are presented as categories instead of continuous data, it is technically incorrect to conduct regression analyses of the data in Table 1. However, if one assumes that the continous data follow the pattern of the seed number categories, there were highly significant quadratic relationships between seed number and fruit diameter, and seed number and fruit $\mathrm{Ca}$, but no relationship between seed number and fruit $\mathrm{Mg}$ or $\mathrm{K}$. The $\mathrm{Ca}$ increases occurred despite the diluting effect of significant increases in fruit size as seed number increased. Tomala and Dilley (1988) have also found that both fruit size and $\mathrm{Ca}$ concentration increased with seed number in 'McIntosh'.

These results 'suggest that seeds enhance translocation of $\mathrm{Ca}$, but not $\mathrm{Mg}$ or $\mathrm{K}$, into the fruit. Seeds may be linked to $\mathrm{Ca}$ accumulation via auxin synthesis. Apple seeds produce auxin (Luckwill, 1953) that can be transported basipetally from the fruit. Stahly and Benson (1970) found that a single spray of TIBA, an inhibitor of auxin transport, applied 28 days after full bloom reduced $\mathrm{Ca}$ concentration in 'Golden Delicious' apples. TIBA also reduced $\mathrm{Ca}$ in tomato fruit, but had no effect on $\mathrm{Mg}$ accumulation (Bangerth, 1976). Calcium transport is acropetal, and is closely linked to basipetal auxin transport (Guzman and dela Fuente, 1984). Thus, greater seed number may result in greater auxin transport from the fruit, which in turn may enhance Ca transport (Kubowicz et al., 1982) into fruit. Marcelle and Lennes (1981) found that injection of IAA into the pedicel of pepper fruit increased their accumulation of $\mathrm{Ca}$, while injection of TIBA reduced it.

Fruit $\mathrm{Ca}$ concentrations at harvest influence the development of physiological disorders in fruit during and following storage, and low $\mathrm{Ca}$ in particular is correlated with occurrence of bitter pit and senescent breakdown (Lidster et al., 1975; Sharples, 1980; Autio et al., 1986). In our study, all fruit Ca concentrations were relatively high (Weis et al., 1980) and occurrence of disorders was too limited for meaningful evaluation. Thus, it can only be presumed that under other conditions an effect of seed number on $\mathrm{Ca}$ might be reflected in retention of fruit quality.

This presumption is supported by evidence from another study. Samples of $\approx 100$ 'McIntosh' apples were collected from each of 50 different commercial orchard blocks throughout Massachusetts at the start of commercial harvest. These blocks represented a wide array of commercial growing conditions and had received no particular treatments. The fruit were stored in $0 \mathrm{C}$ air for 5 months and then kept at $24 \mathrm{C}$ for 1 week. Each fruit was cut equatorially and its seed number and the presence of senescent breakdown was recorded.

Each fruit was placed into one of six categories according to seed number (Table 2 ). The range of seed numbers was wider than that for 'Delicious' (Table 1), since 'McIntosh' characteristically have higher seed number than 'Delicious'. Mean incidence of breakdown among all fruit was $13 \%$. Assuming that continuous seed number followed the pattern of seed number categories, regression analysis showed a significant $(r=-0.30, P<0.001, \mathrm{n}=$ $300)$ linear decrease in percent of fruit developing breakdown as seed number category increased.

To test the relationship further, a $x^{2}$ test of the population distributions of seed numbers among breakdown-containing and breakdown-free fruit showed that these two populations were different $\left(x^{2}=135, P<\right.$ $0.0005)$. The breakdown-afflicted population had a higher proportion of fruit with zero to three seeds and a lower proportion of fruit with six or more seeds than did the breakdown-free population of fruit. Thus, it appears that among these fruit from widely varying growing conditions, seed number was a factor associated with the occurrence of senescent breakdown, a Ca-deficiency disorder.

A comprehensive study of the relationships among seed number, fruit mineral composition at harvest, and retention of fruit quality after harvest of apples is needed. However, the circumstantial evidence is strong that factors contributing to low seed numbers in apples may be contributing to the occurrence of $\mathrm{Ca}$ deficiency. Use of GA (Bukovac, 1963) and its proprietary mixture with BA (Greene et al., 1982) can reduce seed number and increase storage disorders. Environmental conditions and orchard designs that are not conducive to effective pollination or fertilization also may lead to $\mathrm{Ca}$ deficiency in mature fruit and poor postharvest retention of fruit quality. Greater attention to pollination conditions and other factors that may influence seed number in fruit is probably a practical approach to helping cope with the pervasive problem of $\mathrm{Ca}$ deficiency in apples. 


\section{Literature Cited}

Autio, W.R., W.J. Bramlage, and S.A. Weis. 1986. Predicting poststorage disorders of 'Cox's Orange Pippin' and 'Bramley's Seedling' apples by regression equations. J. Amer. Soc. Hort. Sci. 111:738-742

Bangerth, F. 1976. A role for auxin and auxin transport inhibitors on the $\mathrm{Ca}$ content of artificially induced parthenocarpic fruits. Physiol. Plant. 37:191-194.

Bukovac, M.J. 1963. Induction of parthenocarpic growth of apple fruits with gibberellins $\mathrm{A}_{3}$ and A . Bot. Gaz. 124:191-195.

Greene, D.W. and W.J. Lord. 1985. Effect of chemical thinners on 'Delicious' apple trees previously sprayed with $\mathrm{GA}_{4+7}+\mathrm{BA}$. HortScience 20:84-86.

Greene, D.W., W.J. Lord, and W.J. Bramlage. 1982. Effects of gibberellins $\mathrm{A}_{4+7}$ and 6-benzylamino purine on fruit set, fruit characteristics, seed content, and storage quality o 'McIntosh' apples. HortScience 17:653-654.

Guzman, C.C. de and R.K. dela Fuente. 1984.
Polar calcium flux in sunflower hypocotyl segments. 1.The effect of auxin. Plant Physiol. 76:347-352.

Kubowicz, B.D., L.N. Vanderhoef, and J.B Hanson. 1982. ATP-dependent calcium transport in plasmalemma preparations from soybean hypocotyls. Effect of hormone treatments. Plant Physiol. 69:187-191.

Lidster, P.D., S.W. Porritt, G.W. Eaton, and J. Mason. 1975. Spartan apple breakdown as affected by orchard factors, nutrient content, and fruit quality. Can. J. Plant Sci. 55:443-446.

Luckwill, L.C. 1953. Studies of fruit development in relation to plant hormones: 1 .Hormone production by the developing apple seed in relation to fruit drop. J. Hort. Sci. 28:14-24.

Marcelle, R. and G. Lennes. 1981. The effect of IAA and TIBA on calcium transport and accumulation in fruits. Acta Hort. 120:193-198.

Perring, M.A. and C.H. Jackson. 1975. The minera1 composition of apples. Calcium concentration and bitter pit in relation to mean mass per apple. J. Sci. Food Agr. 26:1493-1502.

Sharples, R.O. 1980. The influence of orchard nutrition on the storage quality of apples and pears grown in the United Kingdom, p. 17-28. In: D. Atkinson, J.E. Jackson, R.O. Sharples, and W.M. Waller (eds.). Mineral nutrition of fruit trees. Butterworths, London.

Stahly, E.A. and N.R. Benson. 1976. Calcium levels of 'Golden Delicious' apples as influenced by calcium sprays, 2,3,5-triiodobenzoic acid, and other plant growth regulator sprays. J. Amer. Soc. Hort. Sci. 101:120-122.

Tomala, K. and D.R. Dilley. 1988. Intercellular contents and gradients of calcium and 1-aminocyclopropane-1-carboxylic acid in apples. HortScience 23(3):84. (Abstr.)

Weis, S.A., M. Drake, W.J. Bramlage, and J.H. Baker. 1980. A sensitive method for measuring changes in calcium concentration in 'McIntosh' apples demonstrated in determining effects of foliar calcium sprays. J. Amer. Soc. Hort. Sci. 105:346-349. 